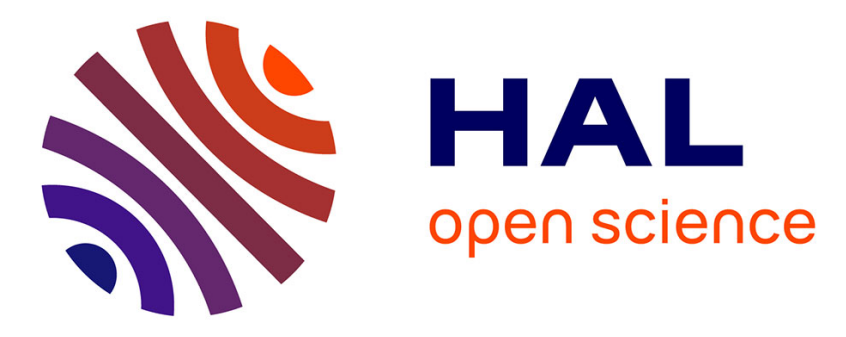

\title{
Nosema ceranae and RNA viruses in European and Africanized honeybee colonies (Apis mellifera) in Uruguay
}

Yamandú Mendoza, Karina Antúnez, Belén Branchiccela, Matilde Anido, Estela Santos, Ciro Invernizzi

\section{To cite this version:}

Yamandú Mendoza, Karina Antúnez, Belén Branchiccela, Matilde Anido, Estela Santos, et al.. Nosema ceranae and RNA viruses in European and Africanized honeybee colonies (Apis mellifera) in Uruguay. Apidologie, 2014, 45 (2), pp.224-234. 10.1007/s13592-013-0241-6 . hal-01234718

\author{
HAL Id: hal-01234718 \\ https://hal.science/hal-01234718
}

Submitted on 27 Nov 2015

HAL is a multi-disciplinary open access archive for the deposit and dissemination of scientific research documents, whether they are published or not. The documents may come from teaching and research institutions in France or abroad, or from public or private research centers.
L'archive ouverte pluridisciplinaire HAL, est destinée au dépôt et à la diffusion de documents scientifiques de niveau recherche, publiés ou non, émanant des établissements d'enseignement et de recherche français ou étrangers, des laboratoires publics ou privés. 


\title{
Nosema ceranae and RNA viruses in European and Africanized honeybee colonies (Apis mellifera) in Uruguay
}

\author{
Yamandú MendozA ${ }^{1}$, Karina AntúNez ${ }^{2}$, Belén BRAnChiccela ${ }^{2}$, Matilde Anido ${ }^{2}$, \\ Estela $\mathrm{SANTOS}^{3}$, Ciro INVERNIZZI ${ }^{3}$ \\ ${ }^{1}$ Instituto de Investigación Agropecuaria, Ruta $11 \mathrm{Km}, 70000$ Colonia, Uruguay \\ ${ }^{2}$ Departamento de Microbiología, Instituto de Investigaciones Biológicas Clemente Estable, Avenida Italia 3318, \\ 11600 Montevideo, Uruguay \\ ${ }^{3}$ Facultad de Ciencias, Iguá 4225, 11400 Montevideo, Uruguay
}

Received 3 May 2013 - Revised 15 August 2013 - Accepted 6 September 2013

\begin{abstract}
Nosema ceranae is one of the causative agents of Nosemosis, a severe disease that affects the honeybee Apis mellifera. The aim of the present work was to compare $N$. ceranae and RNA virus infections in Africanized bees (hybrid of Apis mellifera scutellata and A. m. mellifera) and European (Italian) bees (A. $m$. ligustica) under field conditions. Africanized and Italian healthy colonies were relocated to an Eucalyptus grandis plantation, a place where colonies inevitably acquire Nosemosis. Fifteen and 30 days after that, all colonies presented $N$. ceranae spores although Africanized bees were less infected than Italian bees. Sacbrood virus (SBV) and Black queen cell virus (BQCV) were detected in both races of bees, although Africanized bees presented a lower level of BQCV infection than Italian bees. At the end of the flowering period, Africanized colonies had a larger honeybee population and produced more honey than Italian colonies. These results suggest that Africanized bees may be able to limit N. ceranae and BQCV infections within the colony, and that this may allow them to be more productive.
\end{abstract}

Nosemosis / RNA virus / resistance / bee haplotypes

\section{INTRODUCTION}

Nosemosis is a disease of honeybees (Apis mellifera) caused by microsporidia Nosema apis and $N$. ceranae. These organisms reproduce in epithelial cells of the ventricle of bees affecting digestive functions and leading to malnutrition, physiological aging, and reduction of the

Corresponding author: K. Antúnez, kantunez03@gmail.com

Manuscript editor: Stan Schneider hypopharyngeal glands, causing premature death (Bailey and Ball 1991; Fries 1997; 2010). While $N$. apis was described at the beginning of the last century, it is estimated that $N$. ceranae, whose original host was the Asian honeybee Apis cerana (Fries et al. 1996), "jumped" to A. mellifera at least 20 years ago. Currently, it is distributed worldwide (Higes et al. 2006; Klee et al. 2007; Invernizzi et al. 2009; Fries 2010; Aurori et al. 2011).

Besides the direct damage caused by microsporidia, their presence can be accompanied by other pathogens, such as RNA viruses (Antúnez et al. 2006; vanEngelsdorp et al. 2009; Genersch and Aubert 2010; Rodríguez et al. 2012; Ryba et al. 2012). It has previously been reported that both 
microsporidia are associated with presence of Black queen cell virus (BQCV) (Bailey et al. 1983; Dainat et al. 2012).

In Uruguay, Invernizzi et al. (2009) reported the presence of $N$. ceranae and the absence of $N$. apis in bee samples collected from all over the country, and confirmed that $N$. ceranae was present in bees collected before 1990. Over the last 5 years, several samples of bees from all over the country and collected in different seasons have been analyzed, detecting only $N$. ceranae. Only one sample was co-infected by $N$. apis and $N$. ceranae (K. Antúnez, unpublished data).

Similar results have been reported in Buenos Aires, Argentina (Medici et al. 2011), and Virgina, United States (Traver and Fell 2011). However, this displacement does not always occur, since vanEngelsdorp et al. (2009), Gisder et al. (2010), and Botías et al. (2012; 2013) have reported the presence of both species, suggesting a co-habitation in the case of the United States, Germany, and Spain, respectively.

Different honeybee viruses have also been detected in Uruguay, including Chronic bee paralysis virus (CBPV), Acute bee paralysis virus (ABPV), BQCV, Sacbrood virus (SBV), and Deformed wing virus (DWV) (Antúnez et al. 2005; 2006). The detection of viruses in different provinces, the simultaneous co-infection of colonies by several viruses, and the fact that most analyzed colonies were infected with one or more viruses indicates that they are widespread in the region (Antúnez et al. 2005; 2006).

To date, the only effective treatment against $N$. ceranae is fumagillin; however, this compound is no longer licensed in many countries, including Uruguay (Higes et al. 2008; Williams et al. 2008; MGAP 2010). Selection of honeybee colonies or races resistant to $N$. ceranae could be an alternative to reduce losses associated with this pathogen.

Several studies have been developed in order to evaluate whether there are colonies with differential responses to Nosemosis, but results have been poor and limited. L'Arrivee (1965) infected queens from different geographical origins with $N$. apis spores. No difference in the lifespan of queens from different geographic origins was found, although some queens appeared to tolerate the effects of Nosemosis longer than others. On the other hand, Rinderer and Sylvester (1978) and Rinderer et al. (1983) reported that the response to $N$. apis was related to the longevity of worker bees and suggested that resistance could be improved by selecting bees with a greater longevity. Later, Malone et al. (1995) compared the response to Nosemosis in bees from different European races, also according to the worker bee's lifespan. No differences were found between $A$. m. ligustica, A. m. mellifera, and A. m. carnica. However, the number of spores in dead bees was higher in $A$. $m$. ligustica, than in A. m. mellifera and lower in A. m. carnica. A limitation of that study was that each subspecies was represented by only one colony. In other similar studies, measuring infestation of foraging bees (Malone et al. 1992) or lifespan of worker bees (Malone and Stefanovic 1999), no differences were found between $A$. m. ligustica and A. m. mellifera.

Although $N$. apis is also able to infect $A . m$. scutellata (African bees), and its development in those bees is similar to that seen in European races (Fries et al. 2003), there are no comparative studies that include those bees.

In Uruguay, most bees are Africanized bees resulting from crosses of $A$. m. mellifera (European bees) with A. m. scutellata (African bees) (Burgett et al. 1995; Diniz et al. 2003; Collet et al. 2006). In previous studies, it was found that there were almost $100 \%$ of Africanized bees in north provinces (bordering with Brazil) and a decreasing gradient in the number of Africanized bees, and in the proportion of African genes, from north to south (Diniz et al. 2003). In a recent study, we found that most bees from around the country presented Africanized origin (81\%) (B. Branchiccela, unpublished data). However, it is probable that the gradient still remains when analyzing the proportion of African genes, according to phenotypic characteristics and aggressiveness level of bees. On the other side, in recent years, beekeepers have been introducing queens of $A$. m. ligustica (Italian bees), 
mainly in departments of the west coast, in order to obtain more tame and manageable bees.

Many Uruguayan beekeepers relocate their colonies to commercial plantations of Eucalyptus grandis after the summer honey harvest to take advantage of its autumnal flowering period and to extend the period of honey production. However, those colonies inevitably acquire Nosemosis, presenting high mortality rates if they are not moved out at the end of the flowering period (Invernizzi et al. 2011a; Mendoza et al. 2012). For that reason, plantations of $E$. grandis provide an opportunity to assess the natural incidence of Nosemosis in the colonies.

Considering that honeybee races present different characteristics, including resistance to pathogens, the aim of the present work was to compare the degree of infection of $N$. ceranae and RNA virus in Africanized bees (hybrid of $A . m$. scutellata and A. m. mellifera) and Italian bees (A. m. ligustica) under field conditions.

\section{MATERIALS AND METHODS}

\subsection{Selection of colonies and establishment of the experimental apiary}

In December 2010, a group of Africanized and Italian bee colonies were relocated to the experimental apiary at the Instituto de Investigación Agropecuaria "La Estanzuela" located in Colonia (Southwest province). Africanized bee colonies were obtained from Cerro Largo (Northeast province) while Italian bees were obtained from a beekeeper who had imported queens from Argentina. All colonies were treated with flumetrin in January 2011, to eliminate the presence of Varroa destructor. Twenty-four healthy Africanized and 26 Italian colonies were relocated to an E. grandis plantation located in Rivera (North province) on March 1 (end of summer).

\subsection{Determination of the race of bees}

Eleven Africanized and nine Italian colonies were randomly selected, maintained in ethanol, and their racial origin determined by genetic analysis. Mitochondrial DNA from one bee per colony was assessed, which allowed the differentiation of haplo- types A (African origin), M (West European origin), $\mathrm{C}$ (North Mediterranean origin), and $\mathrm{Y}$ and $\mathrm{O}$ (Near and Middle Eastern origin) (Franck et al. 2001).

The mitochondrial DNA extraction of one bee per colony was carried out as described by C. Aguirre, INIA La Platina, Chile (personal communication) using a modification of the protocol described by Walsh et al. (1991). One posterior leg per bee was incubated at $37^{\circ} \mathrm{C}$ for $30 \mathrm{~min}$ to eliminate the ethanol. After that, Chelex (Sigma) $5 \%$ and proteinase $\mathrm{K}$ (Promega, $20 \mathrm{mg} / \mathrm{ml}$ ) were added and the leg incubated for $1 \mathrm{~h}$ at $55^{\circ}, 15 \mathrm{~min}$ at $99^{\circ}, 1 \mathrm{~min}$ at $37^{\circ} \mathrm{C}$, and $15 \mathrm{~min}$ at $99^{\circ}$. The $2 \mu \mathrm{L}$ of DNA thus extracted were used for the amplification of the intergenic region COI-COII using the primers E2: 5' GGCAGAATAAGTGCATTG3' and H2: 5' CAATATCATTGATGACC3' (Garnery et al. 1998). The $20 \mu \mathrm{L}$ of reaction mixture contained $1 \times$ buffer, $1 \mathrm{mM} \mathrm{MgCl}_{2}, 0.15 \mu \mathrm{M}$ of each primer, $0.5 \mathrm{mM}$ of each $\mathrm{dNTP}$, and $0.5 \mathrm{U} / \mu \mathrm{L}$ of Taq polymerase (Invitrogen). The PCR cycling program consisted of $5 \mathrm{~min}$ at $94{ }^{\circ} \mathrm{C}$, 35 cycles of $45 \mathrm{~s}$ at $92{ }^{\circ} \mathrm{C}, 45 \mathrm{~s}$ at $48^{\circ} \mathrm{C}, 2 \mathrm{~min}$ at $62^{\circ} \mathrm{C}$, and a final extension of $20 \mathrm{~min}$ at $65^{\circ} \mathrm{C}$. The size of the amplified product was determined by electrophoresis on a $1 \%$ agarose gel. The amplified products were digested with FastDigest DraI (Fermentas), according to manufacturer's recommendations, and analyzed under electrophoresis in a $12 \%$ polyacrilamide gel under native conditions for 20-22 h at $300 \mathrm{~V}$, and staining with GelRed (Biotium, USA).

This technique, based on the mithocondrial DNA analysis, allows the determination of the African or European origin of a colony. However, it is possible that honeybees which showed European origin by this analysis had inherited African genes in their nuclear genome. For that reason, those samples were analyzed by a morphometric approach, measuring the wing and femur length of ten bees from each colony. These measures were averaged and the probability of Africanization was calculated (Rinderer et al. 1987).

\subsection{Colony strength estimation}

The day before the relocation of the colonies to the $E$. grandis plantation (February 28) and after the end of the flowering period (June 15), the adult honeybee population and the brood area in each colony were estimated. Hives were carefully opened with very little smoke, spaces between frames were inspected in detail, and 
frames completely covered by adult bees were recorded. Once the adult population was registered, combs were removed from the hive and the brood area was estimated as quarters of frame faces covered by brood (with $1 / 4$ frame face $=210 \mathrm{~cm}^{2}$ ). The area occupied by honey, pollen or empty was not included in the estimation. All determinations were visually performed by the same operator. The honey produced was harvested and weighed at the end of the flowering period (May 4).

\subsection{Quantification of Nosema spp. spores}

In order to detect and quantify the number of Nosema spp. spores, all colonies were sampled before relocation to the E. grandis plantation (February 28) and 15 and 30 days after that (March 15 and 30). In all cases, 30 foraging bees were sampled and individually analyzed following the criteria set by Pickard and ElShemy (1989). For this purpose, the abdomen of each bee was macerated in $1 \mathrm{ml}$ of water and an aliquot of the suspension placed under a microscope at $\times 400$ magnification. The number of spores in 10 fields was then counted, as described by Invernizzi et al. (2011b). The proportion of infected bees and the mean number of spores/field per bee were calculated. The determination of the Nosema species present in each sample was carried out by multiplex PCR, using specific primers for the detection of $N$. apis and $N$. ceranae, as described by Martín-Hernández et al. (2007).

\subsection{Detection and quantification of honeybee viruses}

For the analysis of presence and quantification of honeybee viruses, 11 Africanized colonies and 9 Italian colonies (the same colonies that were analyzed for their racial origin) were sampled at the end of the flowering period (June 15). Worker bees were collected from each colony, transported alive to the laboratory, and immediately stored at $-80{ }^{\circ} \mathrm{C}$ until analysis, in order to avoid RNA degradation.

Ten honeybees were randomly selected from each sample and processed as previously described (Antúnez et al. 2005, 2006). An amount of $140 \mu \mathrm{L}$ of the obtained supernatant was used to perform the RNA extraction using a QIAamp Viral RNA Mini Kit (Qiagen) according to the manufacturer's recommendations, obtaining $80 \mu \mathrm{L}$ of total RNA. Then $5 \mu \mathrm{L}$ of the RNA obtained was subjected to reverse transcription using a QuantiTect reverse transcription Kit (Qiagen), according to manufacturer's recommendations, using a mix of oligo-dT and random primers. This kit also includes an incubation step with gDNA Wipeout Buffer to remove contaminating genomic DNA prior to retrotranscription. cDNA was stored at $-20{ }^{\circ} \mathrm{C}$.

Real-time PCR reactions were carried out using a QuantiTec SYBR PCR Kit (Qiagen) in a final volume of $50 \mu \mathrm{L}$ containing $25 \mu \mathrm{L}$ of mix, $0.3 \mu \mathrm{L}$ of a stock solution of $50 \mu \mathrm{M}$ of each primer, $19.4 \mu \mathrm{L}$ of water, and $5 \mu \mathrm{L}$ of cDNA. The cDNA sample from each colony was tested for the presence of different viruses, using primers previously published for ABPV (Johnson et al. 2009), BQCV (Kukielka et al. 2008), SBV (Kukielka et al. 2008), DWV (Johnson et al. 2009); Israeli Acute Paralysis Virus (IAPV) (Palacios et al. 2008), and Kashmir Bee Virus (KBV) (Stoltz et al. 1995). Amplification of $\beta$-actin cDNA was used for normalization of results, using primers previously described (Yang and Cox-Foster 2005). Negative controls were included, excluding nucleic acids from the reactions, as well as positive controls for each virus (cDNA from previously analyzed samples available at IIBCE, Uruguay). PCR reactions were carried out using a Rotor Gene 6000 (Corbett Research) and the cycling program consisted of an initial activation step at $50^{\circ} \mathrm{C}$ for $2 \mathrm{~min}$ and $95^{\circ} \mathrm{C}$ for $15 \mathrm{~min}$, then 40 cycles of $94^{\circ} \mathrm{C}$ for $15 \mathrm{~s} 50^{\circ} \mathrm{C}$ for $30 \mathrm{~s}$ and $72^{\circ} \mathrm{C}$ for $30 \mathrm{~s}$.

Specificity of the reaction was checked by analysis of the melting curve of the final amplified product (from 65 to $95{ }^{\circ} \mathrm{C}$ ). Relative viral load per sample was estimated by the Pfaffl (2001) method.

\subsection{Statistical analysis}

Data on honeybee population size, brood area, honey production, proportion of $N$. ceranae infected bees, and level of viral infection of Africanized and Italian colonies did not fit the parameters for the use of parametric statistics and were compared using Mann-Whitney rank sum test for unpaired data. For comparison of the mean number of $N$. ceranae spores per field per bee between both groups of colonies, Student's $t$ test was used since data fit the parameters for the use of parametric statistics. $P$ values below 
a

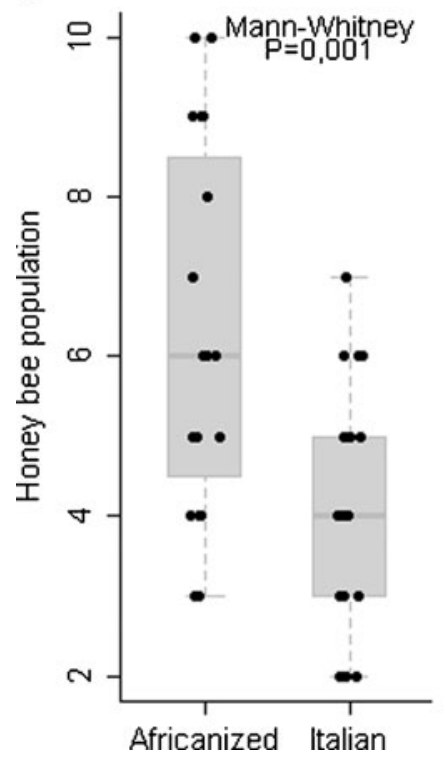

b

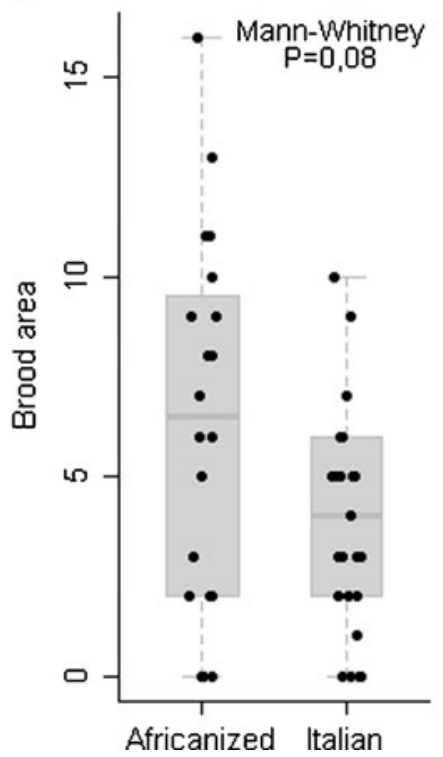

C

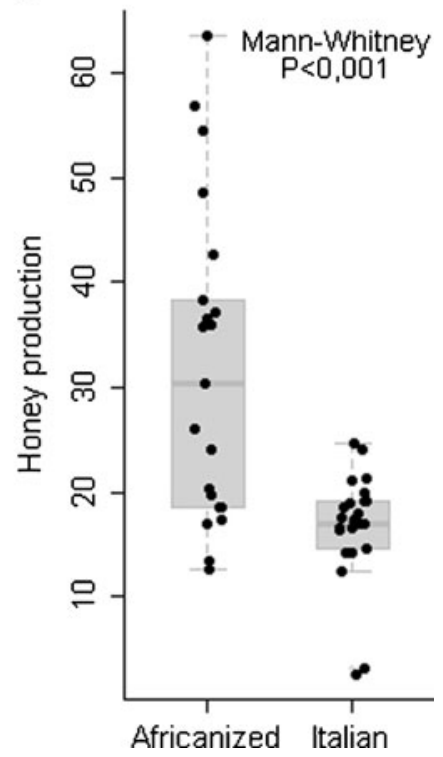

Figure 1. Honeybee population (a), estimated by the number of frames covered by adult bees, brood area (b), estimated as quarters of frame faces covered by brood, and honey production (c) at the end of the flowering period $(\mathrm{Kg})$ of E. grandis in Africanized and Italian beeApis mellifera colonies.

0.05 were considered significant. Statistical analysis was carried out using R software (R Development Core Team 2012).

\section{RESULTS}

\subsection{Determination of the race of bees}

The mitochondrial DNA analysis confirmed the identification of two different groups of colonies: the 11 Africanized colonies presented haplotype A, confirming their African origin, while the 9 Italian colonies presented haplotype C. In these cases, morphometric analysis confirmed their European origin with a $100 \%$ probability.

\subsection{Colony strength estimation}

On February 28, before the relocation of the colonies, no significant differences were found in the honeybee population and brood area between colonies of the two races of bees. The honeybee population averaged $6.2 \pm 1.7$ covered frames in the case of the Africanized colonies, and $6.3 \pm 1.4$ covered frames in the case of the Italian colonies ( $\mathrm{U}=295 ; P=0.75$ ); while the brood area was 26.6 \pm 9.5 quarters of frame faces for the Africanized colonies and $22.4 \pm 6.0$ quarters of frame faces for the Italian colonies $(\mathrm{U}=335 ; P=0.11)$.

At the end of the flowering period, the honeybee population was significantly larger in the Africanized colonies than in the Italian colonies $(\mathrm{U}=391 ; P=0.001)$. Brood area was also larger in the Africanized than in the Italian colonies ( $\mathrm{U}=326 ; P=0.08$, marginally significant), and finally the Africanized colonies produced significantly more honey than the Italian colonies $(\mathrm{U}=427.5 ; P<0.001)$ (Figure 1a-c).

\subsection{Quantification of Nosema spp. spores}

On February 28, the level of Nosema spp. infection was low in all the colonies. Five of the 24 Africanized colonies (21\%) and 7 of the 26 
Day 0

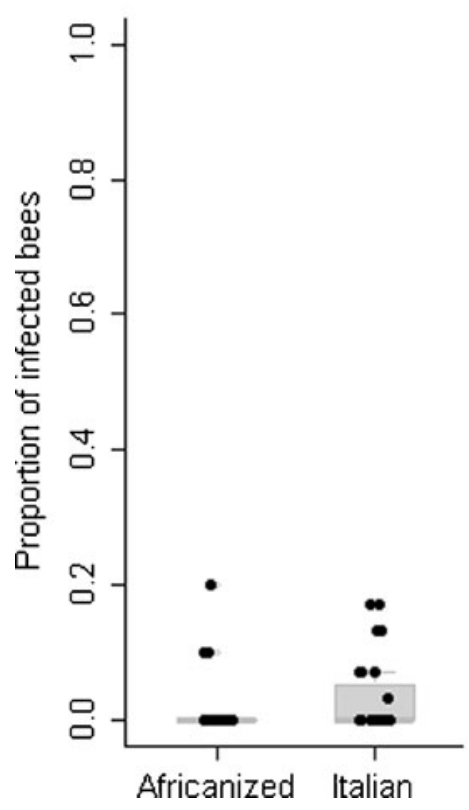

Day 15

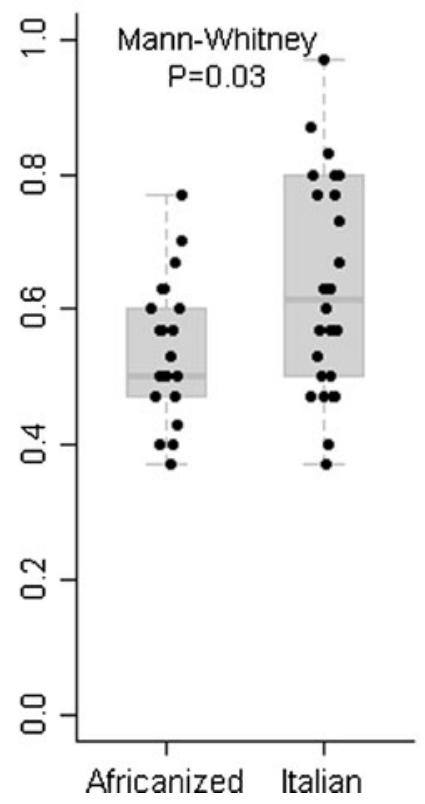

Day 30

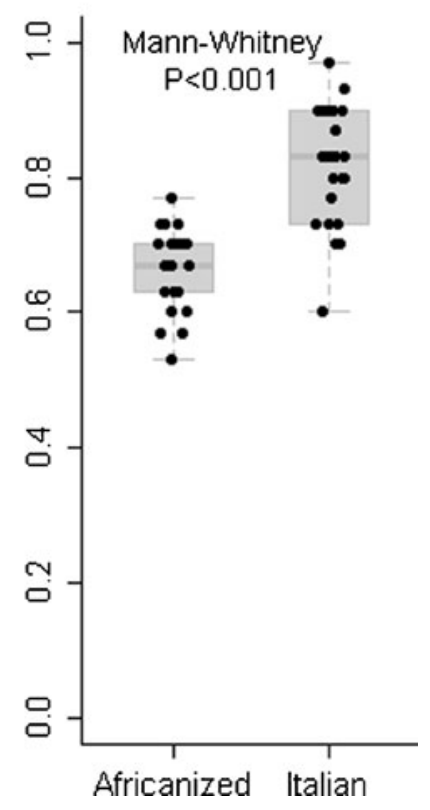

Figure 2. Proportion of Africanized and Italian bees infected with $N$. ceranae, before the relocation of the colonies to E. grandis plantations and 15 and 30 days after that.

Italian colonies $(27 \%)$ had infected bees. However, no significant differences were found in the proportion of infected bees in samples from the Africanized and Italian colonies $(\mathrm{U}=$ $285 ; P=0.50)$ or in the mean number of spores per field per bee $(\mathrm{U}=299 ; P=0.75)$. Results are shown in Figures 2 and 3, respectively.

Fifteen days after the relocation of the apiary, Nosema spp. spores were detected in $100 \%$ of the samples from the Africanized and Italian colonies. The infestation level was lower in the samples from the Africanized colonies than from the Italian colonies, with both a smaller proportion of infected bees per sample $(\mathrm{U}=193 ; P=0.03)$ and a lower mean number of spores per field per bee $(t=$ 5.28; $P<0.001)$ in each Africanized bee analyzed.

These differences were also apparent 30 days after the installation of the apiary. The infestation level was significantly lower in Africanized colonies than in Italian colonies $(\mathrm{U}=45 ; P<$ 0.001 and $t=6.60 ; P<0.001$, respectively).

According to molecular analysis, only $N$. ceranae was detected in the infected samples, while $N$. apis was not detected (data not shown).

\subsection{Detection and quantification of honeybee viruses}

At the end of the E. grandis flowering period, all the analyzed Africanized and Italian colonies (100\%) presented BQCV, while $54 \%$ of Africanized and $67 \%$ of Italian colonies that were analyzed for virus infections presented SBV.

When viral levels were analyzed, a significantly lower level of BQCV was detected in the Africanized colonies than in the Italian colonies ( $\mathrm{U}=22 ; P=0.038$ ), although no differences were found when SBV was analyzed (Figure 4).

ABPV, DWV, IAPV, and KBV were not detected in the analyzed colonies.

\section{DISCUSSION}

Honeybees of different races show distinctive characteristics, among which is differential 
Day 0

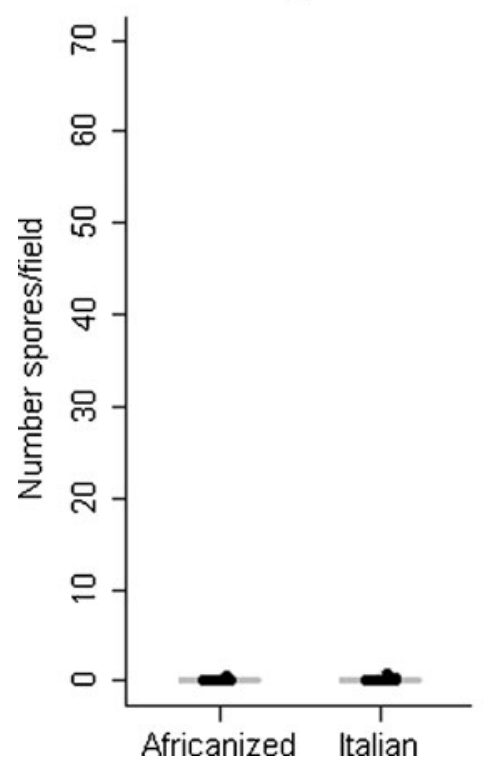

Day 15

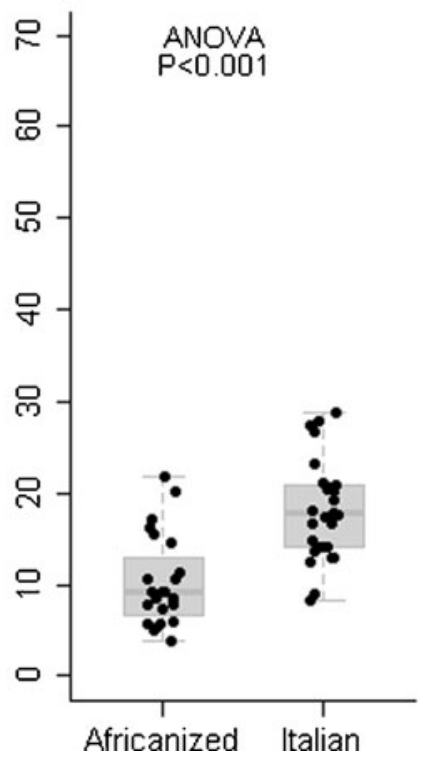

Day 30

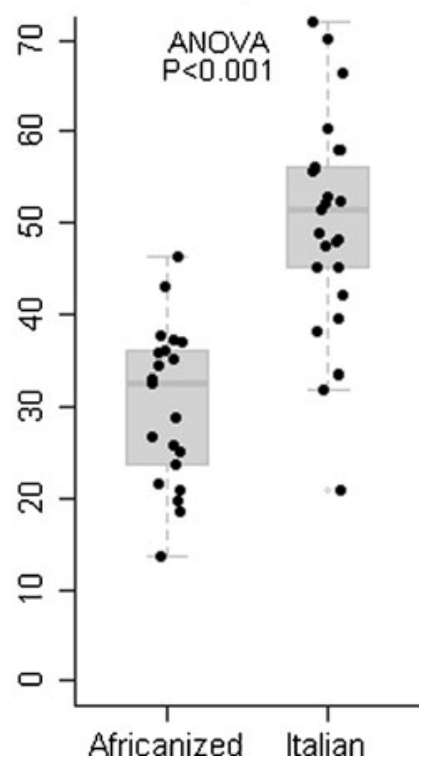

Figure 3. Mean number of spores per field per Africanized or Italian bee infected with N. ceranae, before the relocation of the colonies to E. grandis plantations and 15 and 30 days after that.

resistance to pathogens and parasites because they have been subjected to different disease pressures in their areas of origin (Ruttner 1988; Dietz 1992). Previous studies that compared the response to Nosema spp. among European bees of different races failed to find clear differences (Malone et al. 1992, 1995; Malone and Stefanovic 1999).

In the present work, we present data that support the suggestion that bees from different races present different degrees of infection by $N$. ceranae, and suggest that Africanized bees have the ability to limit the level of infection in a colony. There are important differences between both races of bees that could explain the differential response to $N$. ceranae. Winston and Katz (1981, 1982) found that Africanized worker bees start foraging earlier than Italian bees and have a shorter life-span than Italian bees. So, when capturing forager bees, Africanized bees will be younger and for that reason will be infected with a smaller number of spores. At a colonial level, this would result in a higher number of $N$. ceranae spores circulating in the Italian colonies than in Africanized colonies.

With respect to the presence of different RNA viruses, DWV and ABPV were not detected, although they are widely distributed in Uruguay (Antúnez et al. 2005; 2006). It is possible that the application of acaricides to eliminate $V$. destructor explains the absence of these viruses, since both are strongly associated with the mite (Bowen-Walker et al. 1999; Martin 2001; de Miranda et al. 2010). Recent studies in Uruguay showed a decrease in winter prevalence (June-August) of DWV and ABPV in colonies treated for $V$. destructor in autumn (March) (M. Anido, unpublished data).

IAPV and KBV were also not found, which is consistent with the study by Antúnez et al. (2006) and surveys recently conducted (M. Anido, unpublished data). These two viruses have been detected in northern hemisphere countries and could be associated with massive colony losses observed in recent years (CoxFoster et al. 2007; Maori et al. 2007; de Miranda et al. 2010). 
BQCV

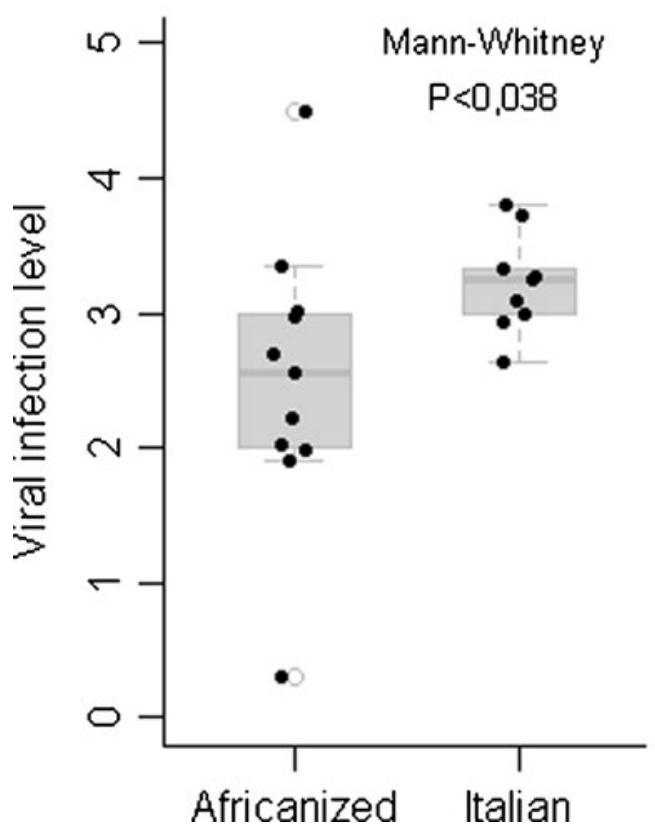

SBV

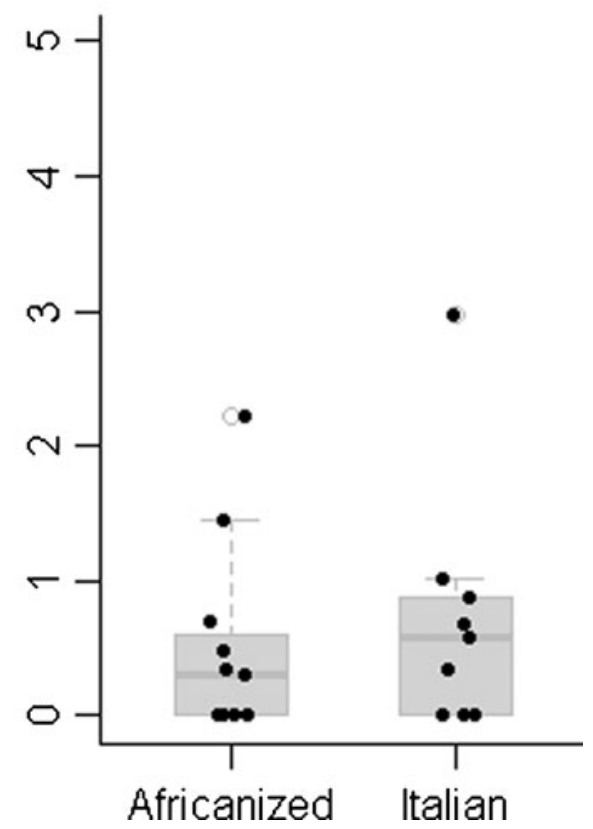

Figure 4. Level of SBV and BQCV infection in Africanized and Italian bee colonies, evaluated by real-time PCR.

BQCV and SBV were detected in Africanized and in Italian bees, although a higher level of BQCV infection was detected in Italian bees. The presence of both viruses has already been reported in Uruguay (Antúnez et al. 2006). Recent studies have shown that BQCV is present in $89 \%$ of the colonies and its prevalence is stable throughout the year (M. Anido, unpublished data).

Previous studies have reported the association between the microsporidia $N$. apis and $N$. ceranae with BQCV (Bailey et al. 1983; Dainat et al. 2012), suggesting that these pathogens can act synergistically (Bacandritsos et al. 2010). Even more, it has been reported that $N$. ceranae is able to cause depression of the immune system (Antúnez et al. 2009), which could favor the infection by viruses.

Italian bees presented higher levels of $N$. ceranae and BQCV infection compared to Africanized bees, while Africanized colonies presented larger populations and produced more honey than Italian colonies. These results suggest that Africanized bees may be able to limit $N$. ceranae and BQCV infections within the colony, and that this may allow the bees to be more productive. However, we cannot rule out that Africanized bees perform better than Italian bees in the particular environment of the $E$. grandis plantations in Uruguay. Africanized bees present greater resistance to brood diseases than Italian bees, especially to $V$. destructor (Martin and Medina 2004; Calderon et al. 2010; Vandame and Palacio 2010).

Nosema ceranae et virus à ARN dans des colonies d'abeilles européennes et africanisées (Apis mellifera) en Uruguay

Nosemose / virus / résistance / haplotypes / abeille

Nosema ceranae und RNA-Viren in europäischen und afrikanisierten Honigbienenvölkern (Apis mellifera) in Uruguay

Nosemosis / RNA-Viren / Resistenz / Bienen-Haplotypen 


\section{REFERENCES}

Antúnez, K., D`Alessandro, B., Corbella, E., Zunino, P. (2005) Detection of chronic bee paralysis virus and acute bee paralysis virus in Uruguayan honeybees. J. Invertebr. Pathol 90, 69-72

Antúnez, K., D’Alessandro, B., Corbella, E., Ramallo, G., Zunino, P. (2006) Honeybee viruses in Uruguay. J. Invertebr. Pathol 93, 67-70

Antúnez, K., Martín-Hernández, R., Prieto, L., Meana, A., Zunino, P., Higes, M. (2009) Immune suppression in the honey bee (Apis mellifera) following infection by Nosema ceranae (Microsporidia). Environ. Microbiol 11, 2284-2290

Aurori, C.M., Dezmirean, D.S., Marghitas, L.A., Moritz, R.F.A. (2011) Nosema apis and N. ceranae in Western honeybee (Apis mellifera) - geographical distribution and current methods of diagnosis. Animal Science and Biotechnologies, Bulletin UASVM, pp. 63-70

Bacandritsos, N., Granato, A., Budge, G., Papanastasiou, I., Roinioti, E., Caldon, M., Falcaro, C., Gallina, A., Mutinelli, F. (2010) Sudden deaths and colony population decline in Greek honey bee colonies. J. Invertebr. Pathol 105, 335-340

Bailey, L., Ball, B.V. (1991) Honey bee pathology. Academic, London

Bailey, L., Ball, B.V., Perry, J.N. (1983) Association of viruses with two protozoal pathogens of the honey bee. Ann. Appl. Biol 103, 13-20

Botías, C., Martín-Hernández, R., Garrido-Bailón, E., González-Porto, A., Martínez-Salvador, A., De La Rúa, P., Meana, A., Higes, M. (2012) The growing prevalence of Nosema cearanae in honey bees in Spain, an emerging problem for the last decade. Res. Vet. Sc. 93, 150-155

Botías, C., Martín-Hernández, R., Barrios, L., Meana, A., Higes, M. (2013) Nosema spp. infection and its negative effects on honey bees (Apis mellifera iberiensis) at the colony level. Vet. Res . doi:10.1186/ 1297-9716-44-25

Bowen-Walker, P., Martin, S.J., Gunn, A. (1999) The transmission of Deformed wing virus between honeybees (Apis mellifera L.) by the ectoparasitic mite Varroa jacobsoni Oud. J. Invertebr. Pathol 73, 101-106

Burgett, M., Shorney, S., Cordara, J., Gardiol, G., Sheppard, W.S. (1995) The present status of Africanized honey bees in Uruguay. Am. Bee J 135, 328-330

Calderon, R.A., van Veen, J.W., Sommeijer, M.J., Sanchez, L.A. (2010) Reproductive biology of Varroa destructor in Africanized honey bees (Apis mellifera). Exp. Appl. Acarol 50, 281-297

Collet, T., Ferreira, K.M., Arias, M.C., Soares, A.E.E., Del Lama, M.A. (2006) Genetic structure of Africanized honeybee populations (Apis mellifera $\mathrm{L}$.) from Brazil and Uruguay viewed through mitochondrial DNA COI-COII patterns. Heredity 97, 329-335
Cox-Foster, D.L., Conlan, S., Holmes, E.C., Palacios, G., Evans, J.D., et al. (2007) A metagenomic survey of microbes in honey bee colony collapse disorder. Science. 318, 283-287

Dainat, B., Evans, J.D., Chen, Y.P., Gauthier, L., Neumann, P. (2012) Predictive markers of honey bee colony collapse. PLoS ONE 7, e32151

de Miranda, J.R., Cordoni, G., Budge, G. (2010) The Acute bee paralysis virus-Kashmir bee virus-Israeli acute paralysis virus complex. J. Invertebr. Pathol 103(Suppl 1), S30-47

Dietz, A. (1992) Honey bees of the world. In: Graham, J.M. (ed.) The hive and the honey bee, pp. 23-71. Dadant, Hamilton, Illinois

Diniz, N.M., Soares, A.E.G., Sheppard, W.S., Del Lama, M.A. (2003) Genetic structure of honeybee populations from southern Brazil and Uruguay. Gen. Mol. Res 26, 47-52

Franck, P., Garnery, L., Loiseau, A., Oldroyd, B.P., Hepburn, H.R., Solignac, M., Cornuet, J.M. (2001) Genetic diversity of the honeybee in Africa: microsatellite and mitochondrial data. Heredity 86, 420-430

Fries, I. (1997) Protozoa. In: Morse, R.A., Flottum, K. (eds.) Honey bee pest, predators and diseases, pp. 57-76. The A.I. Root Company, Medina, OH

Fries, I. (2010) Nosema ceranae in European honey bees (Apis mellifera). J. Invertebr. Pathol 103(Suppl 1), S73-79

Fries, I., Feng, F., da Silva, A., Slemenda, S.B., Pieniazek, N.J. (1996) Nosema ceranae sp. (Microspora, Nosematidae), morphological and molecular characterization of a microsporidian parasite of the Asian honeybee Apis cerana (Hymenoptera, Apidae). Eur. J. Protistol 32, 356-365

Fries, I., Slemenda, S.B., Da Silva, A., Pieniazek, N.J. (2003) African honey bees (Apis mellifera scutellata) and nosema (Nosema apis) infections. J. Apic. Res 42, 13-15

Garnery, L., Franck, P., Baudry, E., Vautrin, D., Cornuet, J., Solignac, M. (1998) Genetic diversity of the west European honey bee (Apis mellifera mellifera and A. m. iberica) I. Mitochondrial DNA. Genet. Sel. Evol 30, $\mathrm{S} 31-\mathrm{S} 47$

Genersch, E., Aubert, M. (2010) Emerging and re-emerging viruses of the honey bee (Apis mellifera L.). Vet. Res 41, 54

Gisder, S., Hedtke, K., Möckel, N., Frielitz, M.-C., Linde, A., Genersch, E. (2010) Five-year cohort study of Nosema spp. in Germany: Does climate shape virulence and assertiveness of Nosema ceranae? Appl. Environ. Microbiol 76, 3032-3038

Higes, M., Martín, R., Meana, A. (2006) Nosema ceranae, a new microsporidian parasite in honeybees in Europe. J. Invertebr. Pathol. 92, 93-95

Higes, M., Martín-Hernández, R., Botías, C., Bailón, E.G., González-Porto, A.V., et al. (2008) How natural infection by Nosema ceranae causes honeybee colony collapse. Environ. Microbiol 10, 2659-2669 
Invernizzi, C., Abud, C., Tomasco, I.H., Harriet, J., Ramallo, G., Campa, J., Katz, H., Gardiol, G., Mendoza, Y. (2009) Presence of Nosema ceranae in honeybees (Apis mellifera) in Uruguay. J. Invertebr. Pathol 101, 150-153

Invernizzi, C., Antúnez, K., Campa, J., Harriet, J., Mendoza, Y., Santos, E., Zunino, P. (2011a) Situación sanitaria de las abejas melíferas en Uruguay. Veterinaria 47, 15-27

Invernizzi, C., Santos, E., Garcia, E., Daners, G., Di Landro, R., Saadoun, A., Cabrera, C. (2011b) Sanitary and nutritional characterization of honeybee colonies in Eucalyptus grandis plantations. Arch. Zootec 60, 1303-1314

Johnson, R.M., Evans, J.D., Robinson, G.E., Berenbaum, M.R. (2009) Changes in transcript abundance relating to Colony Collapse Disorder in honey bees (Apis mellifera). Proc. Natl. Acad. Sci. U.S.A 106, 14790-14795

Klee, J., Besana, A.M., Genersch, E., Gisder, S., Nanetti, A., et al. (2007) Widespread dispersal of the microsporidian Nosema ceranae, an emergent pathogen of the western honey bee, Apis mellifera. J. Invertebr. Pathol 96, 1-10

Kukielka, D., Esperon, F., Higes, M., Sanchez-Vizcaino, J.M. (2008) A sensitive one-step real-time RT-PCR method for detection of deformed wing virus and black queen cell virus in honey bee Apis mellifera. J. Virol. Methods 147, 275-281

L'Arrivee, J.C.M. (1965) Tolerance of honey bees to nosema disease. J. Invert. Pathol 7, 408-413

Malone, L.A., Giacon, H.A., Hunapo, R.J., McIvor, C.A. (1992) Response of New Zealand honey bee colonies to Nosema apis. J. Apicl. Res. 31, 135140

Malone, L.A., Giacon, H.A., Newton, M.R. (1995) Comparison of the responses of some New Zealand and Australian honey bees (Apis mellifera L) to Nosema apis Z. Apidologie 26, 495-502

Malone, L.A., Stefanovic, D. (1999) Comparison of the responses of two races of honeybees to infection with Nosema apis Zander. Apidologie 30, 375-382

Maori, E., Lavi, S., Mozes-Koch, R., Gantman, Y., Peretz, Y., Edelbaum, O., Tanne, E., Sela, I. (2007) Isolation and characterization of Israeli acute paralysis virus, a dicistrovirus affecting honeybees in Israel: evidence for diversity due to intra- and inter-species recombination. J. Gen. Virol 88, 3428-3438

Martin, S.J. (2001) The role of Varroa and viral pathogens in the collapse of honeybee colonies: a modelling approach. J. Appl. Ecol 38, 1082-1093

Martin, S.J., Medina, L.M. (2004) Africanized honeybees have unique tolerance to Varroa mites. Trends Parasitol 20, 112-114

Martín-Hernández, R., Meana, A., Prieto, L., Salvador, A.M., Garrido-Bailon, E., Higes, M. (2007) Outcome of colonization of Apis mellifera by Nosema ceranae. Appl. Environ. Microbiol 73, 6331-6338
Medici, S.K., Sarlo, E.G., Porrini, M.P., Braunstein, M., Eguaras, M.J. (2011) Genetic variation and widespread dispersal of Nosema ceranae in Apis mellifera apiaries from Argentina. Parasitol. Res 110, 859-864

Mendoza, Y., Harriet, J., Campa, J., Katz, H., Ramallo, G., Díaz-Cetti, S., Invernizzi, C. (2012) Control de Nosema ceranae en colonias de abejas (Apis mellifera) en forestaciones de Eucalyptus grandis. Agrociencia. In press.

MGAP (2010) Decreto presidencial 14-6-2010. Oxcitetraciclina y Fumagilina- Retiro y/o limitación de uso en Uruguay [on line] http://www.mgap.gub.uy (accessed on 12 December 2011)

Palacios, G., Hui, J., Quan, P.L., Kalkstein, A., Honkavuori, K.S., et al. (2008) Genetic analysis of Israel acute paralysis virus: distinct clusters are circulating in the United States. J. Virol 82, 6209-17

Pfaffl, M.W. (2001) A new mathematical model for relative quantification in real-time RT-PCR. Nucleic Acids Res 29, e45

Pickard, R.S., El-Shemy, A.A.M. (1989) Seasonal variation in the infection of honeybee colonies with Nosema apis Zander. J. Apic. Res. 28, 93-100

R Development Core Team (2012) R: A language and environment for statistical computing. R Foundation for Statistical Computing, Vienna, Austria. ISBN 3900051-07-0, URL http://www.R-project.org/.

Rinderer, T.E., Sylvester, H.A. (1978) Variation in response to Nosema apis, longevity, and hoarding behavior in a free-mating population of the honey bee. Ann. Entomol. Soc. Am 71, 372-374

Rinderer, T., Sylvester, H., Buco, S., Lancaster, A., Herbert, W., Collins, M., Hellmich, H.L. (1987) Improved simple techniques for identifying Africanized and European honey bees. Apidologie 18, 179-196

Rinderer, T.E., Collins, A.M., Brown, M.A. (1983) Heritabilities and correlations of the honey bee: response to Nosema apis, longevity, and alarm response to isopentyl acetate. Apidologie 14, 79-85

Rodríguez, M., Vargas, M., Gerding, M., Navarro, H., Antúnez, K. (2012) Viral infection and Nosema ceranae in honey bees (Apis mellifera) in Chile. J. Apic. Res 51, 285-287

Ruttner, F. (1988) Biogeography and taxonomy of honeybees. Springer, Berlin

Ryba, S., Titera, D., Schodelbauerova-Traxmandlova, I., Kindlmann, P. (2012) Prevalence of honeybee viruses in the Czech Republic and coinfections with other honeybee disease. Biologia 67, 590-595

Stoltz, D., Shen, X.R., Boggis, C., Sisson, G. (1995) Molecular diagnosis of Kashmir bee virus infection. J. Apic. Res. 34, 153-160

Traver, B.E., Fell, R.D. (2011) Prevalence and infection intensity of Nosema in honey bee (Apis mellifera L.) colonies in Virginia. J. Invertebr. Pathol 107, 43-49

Vandame, R., Palacio, M.A. (2010) Preserved honey bee health in Latin America: A fragile equilibrium due to 
low-intensity agriculture and beekeeping? Apidologie 41, 243-255

vanEngelsdorp, D., Evans, J.D., Saegerman, C., Mullin, C., Haubruge, E., et al. (2009) Colony collapse disorder: a descriptive study. PLoS ONE. 4, e6481

Walsh, P.S., Metzger, D.A., Higuchi, R. (1991) Chelex 100 as a medium for simple extraction of DNA for PCR-based typing from forensic material. Biotechniques 10, 506-513

Williams, G.R., Sampson, M.A., Shutler, D., Rogers, R.E. (2008) Does fumagillin control the recently detected invasive parasite Nosema ceranae in western honey bees (Apis mellifera)? J. Invertebr. Pathol. 99, 342-344
Winston, M.L., Katz, S.J. (1981) Longevity of cross-fostered honeybee workers of European and Africanized races. Can. J. Zool 59, 1571-1575

Winston, M.L., Katz, S.J. (1982) Foraging differences between cross-fostered honeybee workers (Apis mellifera) of European and Africanized races. Behav. Ecol. Sociobiol 10, 125-129

Yang, X., Cox-Foster, D.L. (2005) Impact of an ectoparasite on the immunity and pathology of an invertebrate: evidence for host immunosuppression and viral amplification. Proc. Natl. Acad. Sci. U.S.A 102, 74707475 